\title{
Dendritic and Postsynaptic Protein Synthetic Machinery
}

\author{
Alejandra Gardiol, Claudia Racca, and Antoine Triller \\ Laboratoire de Biologie Cellulaire de la Synapse Normale et Pathologique, Institut National de la Santé et de la Recherche \\ Médicale U497, Ecole Normale Supérieure, 75005 Paris, France
}

There is a growing body of evidence that local protein synthesis beneath synapses may provide a novel mechanism underlying plastic phenomena. In vivo and in vitro biochemical data show that dendrites can perform translation and glycosylation. Using antibodies directed against the eukaryotic protein synthetic machinery, we sought to identify the structures implicated in nonperinuclear translation, namely dendritic and postsynaptic protein synthesis. We performed a morphological and immunocytochemical analysis of ventromedial horn rat spinal cord neurons using both light and electron microscopy.

We show at the cellular level that, in vivo, protein synthesis macrocomplexes (ribosomes and elF-2) as well as the endomembranous system implicated in cotranslational and posttranslational modifications (endoplasmic reticulum and Golgi cisternae) penetrated some dendrites. Membrane-limited organelles of different shape and size are present close to the postsynaptic differentiations of most synapses, independently of their localization on the neuronal surface. We demonstrate (1) that some cisternae are immunoreactive for antibodies against ribosomal proteins and elF-2, and (2) that markers of endoplasmic reticulum $(\mathrm{BiP})$, intermediate compartment, and Golgi complex (rab1, CTR433, TGN38) label subsets of these subsynaptic organelles.

Therefore, these findings indicate that synapses are equipped with the essential elements required for the synthesis and insertion of a well folded and glycosylated transmembrane protein.

Key words: glycine receptor; dendritic mRNA; spinal cord; subsynaptic cisternea; Golgi apparatus; endoplasmic reticulum; immunocytochemistry; confocal microscopy; electron microscopy
Local protein synthesis from mRNAs transported to discrete subcellular locations is now viewed as an alternative way to target proteins to specific microdomains. In neurons, many mRNAs are localized within dendrites (Steward et al., 1996; Steward, 1997). The presence of mRNAs encoding neurotransmitter receptors (Miyashiro et al., 1994; Racca et al., 1997a) raises questions about their perisynaptic synthesis, posttranslational modifications, and subsequent insertion at the postsynaptic membrane. The first morphological indications for a local synthesis derive from the visualization of synapse-associated polyribosomes in dendrites (Bodian, 1965; Steward and Levy, 1982; Steward and Reeves, 1988; for review, see also Steward and Banker, 1992). It is currently believed that the endomembranous system involved in the secretory process, namely rough endoplasmic reticulum (RER) and Golgi apparatus, can extend into proximal portions of the dendritic shaft (Peters et al., 1991). Immunofluorescence studies have demonstrated the presence of components of the translational machinery (Tiedge and Brosius, 1996) and of elements of the endoplasmic reticulum (ER) and Golgi apparatus within some

Received June 26, 1998; revised Oct. 15, 1998; accepted Oct. 15, 1998.

This work was supported by grants from Institut de Recherche sur la Moelle Epinière and from Direction des Recherches Etudes et Techniques (95-126). C.R. was supported by a European Community Training and Mobility of Researchers Marie Curie Research Grant and A.G. by a Ministère de l'Education Nationale, de l'Enseignement Supérieur et de la Recherche Fellowship. We thank A. Dumoulin, M. T. Loones, A. Trembleau, and C. Vannier for their helpful comments, suggestions, and discussion. We also acknowledge C. Antony, U. Bommer, M. Bornens, P. De Camilli, K. Elkon, and B. Goud for generously supplying antibodies.

Correspondence should be addressed to Antoine Triller, Laboratoire de Biologie Cellulaire de la Synapse Normale et Pathologique, Institut National de la Santé et de la Recherche Médicale U497, Ecole Normale Supérieure, 46 rue d’Ulm, F-75005 Paris, France.

Dr. Raccas's present address: Medical Research Council Anatomical Neuropharmacology Unit, Oxford University, Mansfield Road, Oxford OX1 3TH, UK.

Copyright (C) 1998 Society for Neuroscience $\quad 0270-6474 / 98 / 190168-12 \$ 05.00 / 0$ dendrites of cultured hippocampal and neocortical neurons (De Camilli et al., 1986; Lowenstein et al., 1994; Krijnse-Locker et al., 1995; Torre and Steward, 1996). In addition to these morphological findings, biochemical studies have shown an incorporation of precursors of both protein synthesis and glycosylation within dendrites (Rao and Steward, 1991; Torre and Steward, 1992, 1996). These experiments indicate that nonsomatic compartments can perform all the synthesis steps of an integral membrane protein such as a neurotransmitter receptor. However, there is still no evidence for an endomembranous system permitting juxtasynaptic synthesis and posttranslational modifications.

We have recently shown that glycine receptor $\alpha$ subunit (GlyR $\alpha)$ mRNAs are located near synapses in close association with subsynaptic cisternae (Racca et al., 1997a). The nature and function of these membrane-limited structures are still speculative: their association with mRNA under the synapse suggests that they participate in protein synthesis.

The aim of the present work was to characterize the dendritic and perisynaptic constituents potentially involved in the synthesis and glycosylation of synaptic proteins in vivo. We have now characterized by immunocytochemistry, using both light microscopy (LM) and electron microscopy (EM), the distribution of the translational machinery and organelles of the secretory pathway, in neurons of the ventromedial horn of rat spinal cord. We show with LM that initiation factors, ribosomes, ER, and Golgi complex penetrate dendrites. At the ultrastructural level we find that subsynaptic cisternae are: (1) decorated by anti-eIF-2 (initiation factor of the translation) immunoreactivity (IR) and present immunocytochemical characteristics of RER (anti-ribosomal P proteins, ribosomes; and BiP, ER chaperone); (2) surrounded by rab1 (ER to Golgi traffic) immunoreactivity; and (3) labeled with 


\begin{tabular}{|c|c|c|}
\hline Organelles/Molecular complexes & Concentration & Reference \\
\hline \multicolumn{3}{|l|}{ Endoplasmic reticulum } \\
\hline $\mathrm{BiP}(\mathrm{mAb})$ & $1: 200$ & StressGen Biotech, Victoria, Canada \\
\hline \multicolumn{3}{|l|}{ Initiation factor } \\
\hline eIF-2 $\beta$ (rabbit) & $1: 200$ & Bommer et al., 1988 \\
\hline \multicolumn{3}{|l|}{ Ribosomes } \\
\hline Ribosomal P proteins (human) & $1: 500$ & Elkon et al., 1985 \\
\hline $\begin{array}{l}\text { Intermediate compartment and cis } \\
\text { rab1 (rabbit) }\end{array}$ & $1: 100$ & Saraste et al., 1995 \\
\hline \multicolumn{3}{|l|}{ Golgi apparatus } \\
\hline CTR 433 (mAb) & $1: 50$ & Jasmin et al., 1989 \\
\hline TGN 38 (rabbit) & $1: 500$ & Wilde et al., 1992 \\
\hline \multicolumn{3}{|l|}{ Presynaptic markers } \\
\hline Synapsin (rabbit) & $1: 1000$ & Bloom et al., 1979; De Camilli et al., 1979 \\
\hline Synaptophysin (mAb) & $1: 20$ & Boehringer Mannheim, Indianapolis, IN \\
\hline
\end{tabular}

CTR433 (medial Golgi) and anti-TGN38 (trans-Golgi) antibodies. These data indicate that membrane-limited elements located near synapses may have different functional characteristics. We postulate that they form a complex subsynaptic apparatus involved in the local synthesis, glycosylation, and insertion of proteins in the synaptic plasma membrane.

Some of the results have been presented in abstract form (Gardiol et al., 1997).

\section{MATERIALS AND METHODS}

Several antibodies (Table 1) directed against the protein synthetic machinery including the organelles were used for LM and EM.

Tissue preparation. Adult Sprague Dawley female rats (150-170 gm; Janvier, France) were deeply anesthetized with sodium pentobarbital (60 $\mathrm{mg} / \mathrm{kg}$ body weight, i.p.) and perfused intracardially with either $4 \%$ paraformaldehyde (PFA) in $0.1 \mathrm{M}$ PBS, $\mathrm{pH} 7.2$, for LM experiments and in situ hybridization (ISH) or 4\% PFA and $0.1 \%$ glutaraldehyde in PBS followed by $4 \%$ PFA in PBS for EM immunocytochemistry. Spinal cords were removed and post-fixed overnight at $4^{\circ} \mathrm{C}$ in $4 \%$ PFA in PBS. Vibratome sections were collected in cold PBS and processed as described for each specific protocol.

Fluorescent immunocytochemistry. Vibratome sections $(50 \mu \mathrm{m})$ were incubated for $20 \mathrm{~min}$ in $50 \mathrm{~mm} \mathrm{NH}_{4} \mathrm{Cl}$ in PBS to quench the free aldehyde groups. After PBS rinses $(3 \times 10 \mathrm{~min})$, sections were preincubated for $10 \mathrm{~min}$ in $0.1 \%$ Triton X-100 and $0.1 \%$ bovine gelatin in PBS. Primary antibodies (Table 1) were incubated in the same buffer overnight at $4^{\circ} \mathrm{C}$. Sections were then rinsed in PBS $(4 \times 10 \mathrm{~min})$ and incubated for $2 \mathrm{hr}$ at room temperature with fluorescent secondary antibodies (1:500 in $0.1 \%$ bovine gelatin in PBS): carboxymethyl indocyanine (Cy3)-goat anti-mouse or anti-rabbit IgG (Jackson ImmunoResearch, West Grove, PA) or fluorescein isothiocyanate (FITC)-goat anti-human IgG (Jackson ImmunoResearch), depending on the primary antibody host. Incubations were followed by PBS washes $(4 \times 10 \mathrm{~min})$. Finally, sections were mounted on slides with Vectashield (Vector Laboratories, Burlingame, CA) and observed with (1) a Leica epiluorescent microscope and images acquired using a Hamamatsu CCD camera or (2) a Molecular Dynamics confocal laser scanning microscope. In these and following experiments, the background noise was reduced by applying a Gaussian filter to the confocal optical sections. Omission of any primary antibody or any single step in the development of fluorescent immunocytochemistry resulted in no labeling of any cells.

Double immunocytochemistry. Fifty micrometer sections were treated and permeabilized as described above for single immunocytochemistry. Double-immunolabelings were performed by incubating sections, overnight at $4^{\circ} \mathrm{C}$, in presence of (1) mouse anti-BiP and rabbit anti-TGN38, (2) mouse CTR433 and rabbit anti-TGN38, (3) rabbit anti-TGN38 and mouse anti-synaptophysin, or (4) mouse CTR433 and rabbit antisynapsin. The antibodies were diluted in the same buffer as above (for concentrations, see Table 1). The following day, sections were rinsed in
PBS $(4 \times 10 \mathrm{~min})$. Primary antibodies were detected with the following combinations: Cy3-goat anti-rabbit IgG antibody (1:500) and FITC-goat anti-mouse IgG antibody (1:500) in PBS, $2 \mathrm{hr}$ at room temperature; or FITC-goat anti-rabbit IgG antibody (1:500) and Cy3-goat anti-mouse $\mathrm{IgG}$ antibody (1:500) in PBS, $2 \mathrm{hr}$ at room temperature. All of these secondary antibodies were from Jackson ImmunoResearch.

After washes in PBS $(4 \times 10 \mathrm{~min})$, sections were mounted on slides with Vectashield (Vector Laboratories) and observed with a Leica confocal laser scanning microscope equipped with appropriate filters for simultaneous detection of FITC and Cy3 fluorochromes. Controls included the independent omission of each single major step of the immunocytochemistry protocol, one at a time.

Fluorescent nonradioactive in situ hybridization and immunocytochemistry. The GlyR $\alpha 2$ oligonucleotide probe (residues 1682-1726; Kuhse et al., 1990; Malosio et al., 1991) has been described previously (Malosio et al., 1991; Racca et al., 1997a). ISH was as previously described by Racca et al. (1997a). Briefly, spinal cord, $30 \mu \mathrm{m}$ sections were permeabilized with $0.1 \%$ Triton $\mathrm{X}-100$ in PBS. The free-floating sections were pretreated for $3 \mathrm{hr}$ at $42^{\circ} \mathrm{C}$ with prehybridization buffer $(4 \times \mathrm{SSC}$ buffer, $1 \times$ Denhardt's solution, and $10 \mu \mathrm{g} / \mathrm{ml}$ yeast tRNA), and then hybridized overnight at $42^{\circ} \mathrm{C}$ in hybridization buffer $(50 \%$ formamide, $600 \mathrm{~mm} \mathrm{NaCl}$, $80 \mathrm{~mm}$ Tris- $\mathrm{HCl}, \mathrm{pH} 7.5,4 \mathrm{~mm}$ EDTA, and $10 \mu \mathrm{g} / \mathrm{ml}$ yeast tRNA) containing $10 \mathrm{nM} 3^{\prime}$ end digoxigenin (DIG)-labeled oligonucleotides as previously described (Trembleau et al., 1994). The following day, sections were rinsed in $2 \times$ SSC and $1 \times$ SSC for $1 \mathrm{hr}$ each, and the high stringency wash was in $0.1 \times \mathrm{SSC}$ at $42^{\circ} \mathrm{C}$ for $50 \mathrm{~min}$. Detection of mRNAs and BiP was contemporaneously carried using (1) sheep antiDIG antibody (Boehringer Mannheim, Indianapolis, IN; 1:1000 in 100 mm Tris-HCl, pH 7.5, $150 \mathrm{~mm} \mathrm{NaCl}, 2 \% \mathrm{BSA}$, and $0.3 \%$ Triton X-100, overnight at $4^{\circ} \mathrm{C}$ ) and Cy3-donkey anti-sheep IgG antibody (Jackson ImmunoResearch; 1:800 in PBS-1\% BSA, 2 hr at room temperature) for ISH; and (2) anti-BiP antibody (1:200 in $100 \mathrm{~mm}$ Tris- $\mathrm{HCl}, \mathrm{pH} 7.5,150$ $\mathrm{mm} \mathrm{NaCl}, 2 \% \mathrm{BSA}$, and $0.3 \%$ Triton $\mathrm{X}-100$, overnight at $4^{\circ} \mathrm{C}$ ) followed by biotinylated rabbit anti-mouse IgG (Jackson ImmunoResearch; 1:500 in PBS, $2 \mathrm{hr}$ at room temperature) and FITC-streptavidin (Jackson ImmunoResearch, 1:200 in PBS, $3 \mathrm{hr}$ at room temperature) for BiP detection.

Each incubation was followed by washes in PBS $(3 \times 10 \mathrm{~min})$. Finally, sections were mounted on slides with Vectashield (Vector Laboratories) and observed with a Leica confocal laser scanning microscope equipped with appropriate filters for simultaneous detection of FITC and Cy3 fluorochromes. Sense and random oligonucleotide probes and omission of any oligonucleotides or primary antibody or any single step in the development of fluorescent ISH and immunocytochemistry resulted in no labeling of any cells.

Pre-embedding immunogold electron microscopy. Vibratome sections $(100 \mu \mathrm{m})$ were treated for $20 \mathrm{~min}$ with $50 \mathrm{mM} \mathrm{NH} \mathrm{NH}_{4} \mathrm{Cl}$ in PBS and preincubated in $0.1 \%$ bovine gelatin in PBS $(3 \mathrm{hr})$. Then, sections were incubated in primary antibodies: (1) mouse anti-BiP; (2) human antiribosomal P proteins; (3) rabbit anti-eIF-2 $\beta$; (4) rabbit anti-Rab1; (5) mouse CTR433; and (6) rabbit anti-TGN38 (see Table 1 for dilutions and 
references) diluted in $0.05 \%$ Triton $\mathrm{X}-100$ and $0.1 \%$ bovine gelatin in PBS, at $4^{\circ} \mathrm{C}, 48 \mathrm{hr}$.

Sections were rinsed in PBS $(3 \times 10 \mathrm{~min})$, post-fixed for $5 \mathrm{~min}$ in $4 \%$ PFA in PBS, rinsed again, and incubated with gold-conjugated secondary antibodies (goat anti-rabbit, goat anti-human, goat anti-mouse, 1:50-1: 100 depending on batch; Nanoprobes, Stony Brook, NY) for $24 \mathrm{hr}$ in $0.1 \%$ fish gelatin (Sigma, St. Louis, MO) in PBS at $4^{\circ} \mathrm{C}$. The following day sections were rinsed in $0.1 \%$ fish gelatin-PBS $(3 \times 10 \mathrm{~min})$, PBS $(1 \times$ $10 \mathrm{~min})$, then post-fixed in $1 \%$ glutaraldehyde in PBS (5 min). After PBS washes $(3 \times 10 \mathrm{~min})$, sections were rinsed several times in distilled water. Silver-enhancement (HQS kit; Nanoprobes) was performed in the dark for 5-7 min and stopped by several rinses in cold distilled water. A gold-toning procedure (Trembleau et al., 1994) was used to protect silver particles against osmium displacement. After PBS rinses $(2 \times 10 \mathrm{~min})$, sections were osmicated, dehydrated, and flat-embedded in Araldite resin. Ultrathin sections of ventromedial spinal cord laminae $(70-90 \mathrm{~nm})$ were countercolored with uranyl acetate and lead citrate and visualized with a Jeol CX-II transmission electron microscope at $80 \mathrm{kV}$.

Pre-embedding immunoperoxidase electron microscopy. Sections were pretreated as described above and incubated in anti-BiP or anti-TGN38 (see Table 1 for dilutions and references) diluted in $0.05 \%$ Triton X-100 and $0.1 \%$ bovine gelatin in PBS, at $4^{\circ} \mathrm{C}$, for $48 \mathrm{hr}$. Subsequently, sections were rinsed in PBS $(3 \times 10 \mathrm{~min})$, incubated in the biotinylated antibodies, goat anti-mouse IgG (Sigma), or goat anti-rabbit (Vector Laboratories, $2 \mathrm{hr}$ at room temperature, 1:200 in PBS 1\% BSA), and finally with avidin-biotin peroxidase complex for $1 \mathrm{hr}$ at room temperature (ABC Elite kit; Vector Laboratories, 1:400 in PBS). After rinses with $50 \mathrm{~mm}$ Tris- $\mathrm{HCl}, \mathrm{pH} 7.5(3 \times 5 \mathrm{~min})$, the peroxidase was revealed by incubating the sections in 3,3'-diaminobenzidine tetrachloride (DAB) and hydrogen peroxide (Sigma-Fast; Sigma). The reacted sections were rinsed in PBS $(3 \times 10 \mathrm{~min})$, osmicated, embedded, and processed for EM as described above. Measurements for morphometrical analysis were performed on micrographs at a final magnification of $18000 \times$.

\section{RESULTS}

We have analyzed the distribution of components of the protein synthesis and posttranslational modification machineries in neurons of the ventromedial portion of adult rat cervical spinal cord by immunocytochemistry at both the LM and EM levels. We focused on the distribution of markers of organelles (RER, intermediate compartment and Golgi apparatus) and on one marker of a member of the macromolecular complexes involved in the initiation of translation (eIF-2), as well as on the P proteins of ribosomes.

\section{Organelles and macromolecular complexes in somata and dendrites}

BiP, ribosomal $P$ proteins, eIF-2

The immunoglobulin-binding protein $\mathrm{BiP}$ is a chaperone protein bearing a KDEL signal thus residing in the ER (Haas and Wabl, 1983; Bole et al., 1986; Villa et al., 1991; Gething and Sambrook, 1992). Using a monoclonal antibody against BiP and digitalized LM microscopy we showed an intense discontinuous immunofluorescence signal within somata and dendrites (Fig. $1 A_{1}$, confocal; inset, CCD camera). The nucleoplasm of neurons was devoid of fluorescence, but the nuclear envelope was strongly labeled. The intense blob-shaped somatic staining likely corresponds to the Nissl bodies around the nucleus (Fig. $1 A_{1}$ ). Within dendrites these fluorescent blobs (Fig. $1 A_{2}$, crossed arrow) were less numerous. Furthermore, smaller sparse spots, often elongated, could be detected along dendrites, where the total signal was lower (Fig. $1 A_{2}$, arrows). These small fluorescent spots probably correspond to cisternal elements scattered throughout the dendroplasm, including those under the border of the neurite most likely corresponding to the subsynaptic ER (see EM below).

A human serum with anti-ribosomal activity obtained from a systemic lupus erythematous patient was used to localize ribosomes. It targets three ribosomal phosphoproteins (P0, P1, and
P2; Elkon et al., 1985, 1986). Confocal microscopy revealed blocks of staining within somatic cytosol (Fig. $1 B_{1,2}$ ). This heavy labeling in the perikarya and initial portions of dendrites likely corresponds to ribosomes associated with cisternae of the Nissl bodies. The dendritic signal was more discontinuous with triangular-shaped accumulation of ribosomes at branch points (Fig. $1 B_{2}$ ) and at discrete sites under the margin of dendrites (Fig. $1 B_{1}$ ). Occasionally, we observed a faint fluorescence signal underscoring the dendritic border (Fig. $1 B_{1,2}$ ).

The association of initiation factors with the ribosomal subunits is a key event in the regulation of eukaryote protein translation rate (Rhoads, 1993). We used an antibody against eIF-2 $\beta$ (Bommer et al., 1988), one of the subunits of the initiation factor-2 (eIF-2). The heaviest signal was present in the soma as bright punctiform staining (Fig. $1 C_{1}$ ). An intense dot-like eIF-2 $\beta$ staining was also found over dendrites. These spots tended to accumulate at discrete sites with no visible morphological features (Fig. $1 C_{2}$ ). As for ribosomal $\mathrm{P}$ proteins, the nuclei of eIF-2positive cells were devoid of labeling.

\section{Rab1, CTR, TGN38}

We used several markers to analyze the distribution of the Golgi apparatus: rab1 (Saraste et al., 1995) for the compartment between the ER and the Golgi apparatus, including the cis-side of it, CTR 433 (Jasmin et al.,1989) for the medial cisternae, and anti-TGN38 (Wilde et al., 1992) for the trans-most Golgi cisternae and trans-Golgi network. The antibody against rab1 recognizes a small G-protein involved in the traffic between the ER and the Golgi apparatus. The CTR433 antibody recognizes an epitope of unknown function, whereas that against TGN38 recognizes a structural protein involved in the budding at the trans-side of the Golgi complex (Stanley and Howell, 1993). With the anti-rab1, small structures were labeled over somata and dendrites (Fig. $\left.1 D_{1}\right)$. For the medial and trans-Golgi markers, the labeling formed a thread-shaped network enclosing the nucleus (Fig. $\left.1 D_{2,3}\right)$. In the initial portion of dendrites, the threads assumed a more parallel distribution before penetrating the shaft. The labeling extended into dendrites sometimes as far as the second branching point (Fig. $1 D_{3}$ ). The dendritic Golgi network was composed of a single tubule or of a few tubules running parallel, along the central core (see also Fig. $2 D_{1-4}$ ). As seen on projections of confocal sections (Fig. $1 D_{2,3}$ ), the dendritic network in continuity with the somatic one was present only in few dendrites issuing from a given soma. Quantifications for TGN38-IR indicated that in $34,40,22,3$, and $1 \%$ of neurons $(n=469)$ the Golgi-IR network penetrated one, two, three, four, and five dendrites, respectively. The number of dendrites containing Golgi elements was certainly underestimated because we could not take into account the presence of small and discontinuous structures that could only be detected with high-resolution confocal microscopy (Fig. $2 B_{1,2}$, see De1) and were shown to be postsynaptic with EM (see Fig. 4)

\section{Spatial relationship of markers of the synthetic machinery within the somatodendritic compartment} GlyR $\alpha 2$ subunit $m R N A$ and BiP-positive compartments

In a previous study, we showed that GlyR $\alpha 1$ and $\alpha 2$ subunit mRNAs were present in the somatodendritic compartment of neurons of the rat spinal cord (Racca et al., 1997a, 1998). These mRNAs were found to be partially associated with cisternae, beneath synapses (Racca et al., 1997a). Therefore, we performed double-labeling experiments for GlyR $\alpha 2$ mRNA and BiP. We 

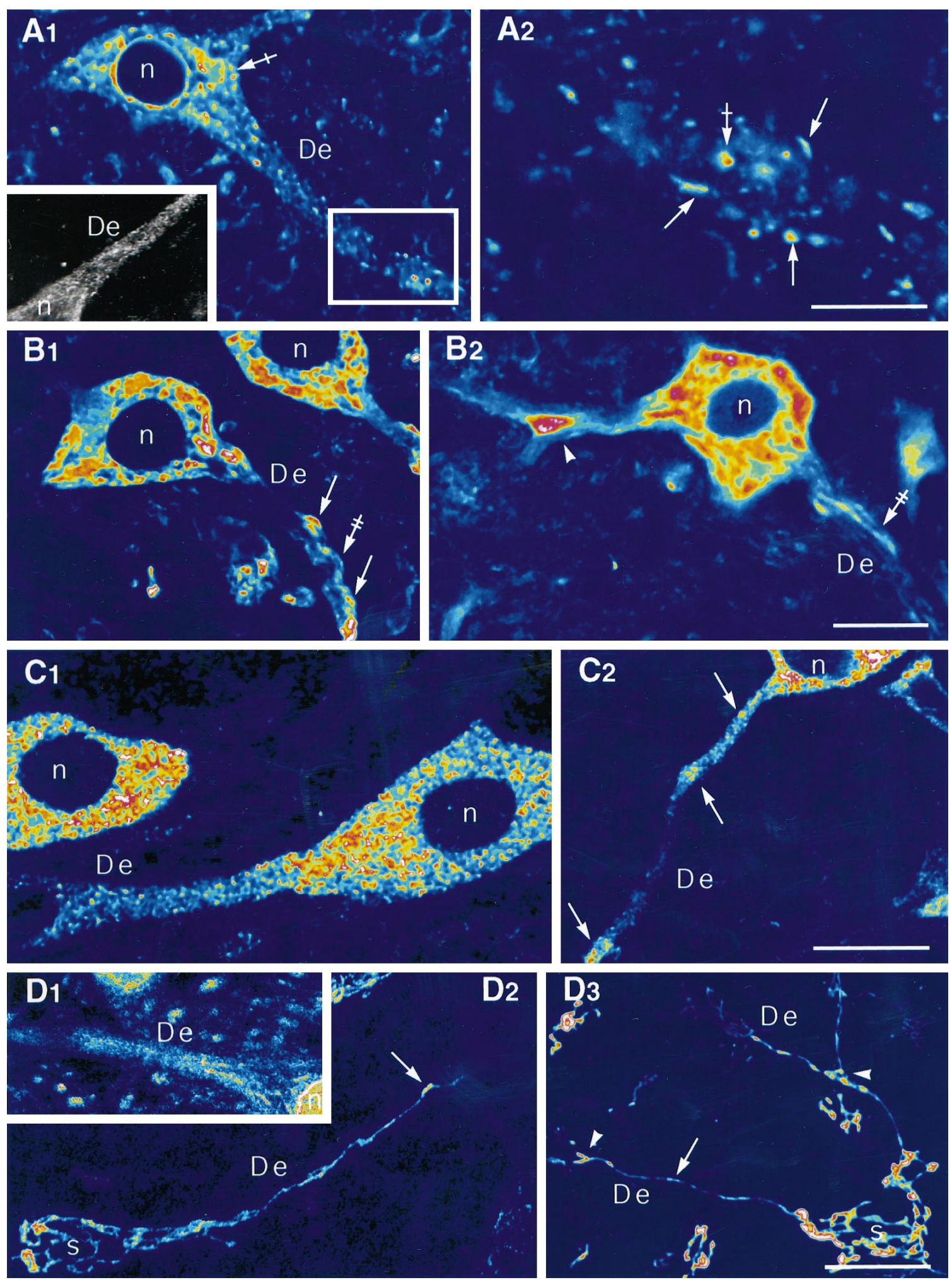

Figure 1. Somatic and dendritic distribution of BiP-, ribosomal P protein-, eIF-2 $\beta$-, CTR433-, and TGN38-IRs. $A_{1}, A_{2}$, Discontinuous distribution of BiP-IR in the soma and dendrites. The IR can form blobs (crossed arrows) or elongated structures (arrows). $A_{2}$, Higher magnification of the box in $A_{1}$. Note that in the nonconfocal image $\left(A_{1}\right.$, inset $)$ the IR fills the dendrite. $B_{1}, B_{2}$, Distribution of ribosomal P protein-IR with intense staining forming blocks (arrows) within a weaker staining (double-crossed arrows). The ribosomal P protein-IR tends to accumulate at branch points (arrowhead). $C_{1}$, $C_{2}$, eIF- $2 \beta$-IR is present throughout the somatodendritic compartment with local accumulations (arrows) within dendrites. $D_{1}$, Discontinous rab1-IR in a dendrite. $D_{2}$, Dendritic extension of CTR433-IR thread (arrows) connected with the somatic network. $D_{3}$, Dendritic extension of TGN38-IR thread (arrow) extending after the first branch point (arrowheads) and connected with the somatic network. In all cases, nuclei were devoid of labeling. $A_{1}, A_{2}$, $B_{1}, B_{2}, C_{1}, C_{2}$, and $D_{1}$ are confocal sections. $D_{2}$ and $D_{3}$ are maximum intensity projections obtained from series of confocal sections. The inset in $A_{1}$ is a CCD camera image. De, Dendrites; $n$, nucleus; $s$, soma. Scale bars, $A_{1-2}: A_{1}, 20 \mu \mathrm{m}$; inset, $30 \mu \mathrm{m} ; A_{2}, 6 \mu \mathrm{m} ; B_{1-2}: B_{1}, 20 \mu \mathrm{m} ; B_{2}, 28 \mu \mathrm{m} ; C_{1-2}: C_{1}, C_{2}$, $20 \mu \mathrm{m} ; D_{1-3}: D_{1}, 29 \mu \mathrm{m} ; D_{2}, D_{3}, 20 \mu \mathrm{m}$. 

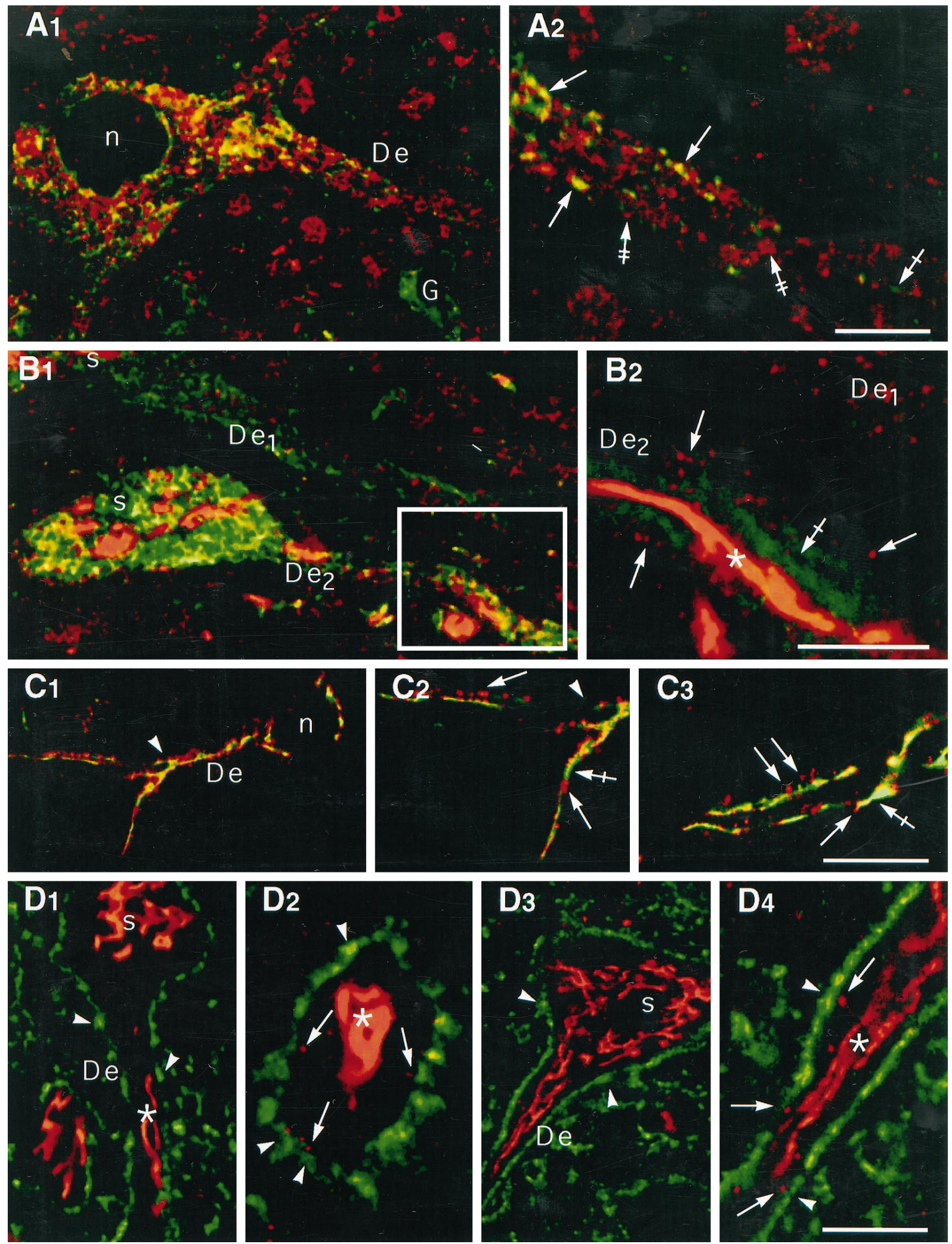

Figure 2. Spatial relationships of elements of the synthetic machinery. $A_{1}, A_{2}$, ISH signal $\left(A_{2}\right.$, red, double-crossed arrows) corresponding to GlyR $\alpha 2$ mRNA is partially colocalized $\left(A_{2}\right.$, yellow, arrows $)$ with the BiP-IR $\left(A_{2}\right.$, green, crossed arrow $)$ associated with the ER. Note that a glial cell $\left(A_{1}, G\right)$ presents only BiP-IR. $A_{1}$ and $A_{2}$, Low and high magnifications, respectively. $B_{1}, B_{2}$, TGN38- (red) and BiP- ( green) IRs. One dendrite $\left(D e_{2}\right)$ displays a central thread (asterisk) surrounded by discontinuous TGN38-IR elements (arrows). Another dendrite $\left(D e_{1}\right)$ exhibits globular TGN38-IR but not thread-like IR Note that the BiP-IR (crossed arrow) does not colocalize with TGN38-IR. $C_{1}-C_{3}$, CTR-IRs (red, arrows) and TGN38-IRs (green, crossed arrows) are present within the same dendrites and extend over the first branch point (arrowheads). The yellow color corresponds to superposition of fluorescent signal within the thickness of the confocal sections. $D_{1}-D_{4}$, Relationship between Golgi markers (red) and synaptic boutons (green). The main Golgi thread (asterisks) is located in the center of the dendrites. Some elements immunopositive for Golgi markers (arrows) are in (Figure legend continues.) 
focused on GlyR $\alpha 2$ mRNA localization because GlyR $\alpha 2$ and $\alpha 1$ mRNAs have the same distribution pattern (Racca et al., 1997a, 1998). As shown in confocal sections of double-labeling experiments (Fig. $2 A_{1,2}$ ), the ISH signal (red) and the immunolabeling for $\mathrm{BiP}$ (green) were detected in somata and dendrites. In somata and dendrites, some spots displayed the two IRs (yellow). In dendrites, these yellow spots were found mainly at the border of dendrites (Fig. $2 \mathrm{~A}_{2}$ ). GlyR $\alpha 2$ mRNA-spots (red) not associated with BiP-labeling likely correspond to transport granules of mRNA (Racca et al., 1997a). Moreover, in dendrites, highresolution confocal microscopy revealed that GlyR $\alpha 2$ mRNA and $\mathrm{P}$ ribosomal antigen are colocalized (Racca et al., 1997b).

\section{BiP-positive compartments and TGN cisternae}

The spatial relationship between the ER and the Golgi complex, particularly within dendrites, was investigated in doubleimmunofluorescence experiments (Fig. $2 B_{1,2}$ ) using anti-TGN38 (red) and anti-BiP (green) antibodies. As expected from singlelabeling experiments, BiP and TGN38-IRs were detected in somata and dendrites (Fig. $2 B_{1}$ ). In dendrites at higher magnification, small TGN38-IR spots (Fig. $2 \mathrm{~B}_{2}$ ) were detected at the border of the dendrite. They were not continuous with the centrally located apparatus. In most dendrites these small TGN38-IR spots were detected even in the absence of central labeling (Fig. $2 B_{1,2}$, De1). High-resolution confocal microscopy observations (Fig. $2 B_{2}$ ) showed that BiP- and TGN38-IRs were not colocalized.

\section{Golgi complex}

Double-labeling experiments with CTR433-TGN38, CTR433synapsin, and TGN38-synaptophysin couples of antibodies were performed to define the distribution of the constitutive elements of the Golgi complex. Synapsin and synaptophysin are both markers of synaptic terminals (Bloom et al., 1979; De Camilli et al., 1983; Wiedenmann and Franke, 1985). We observed that CTR433- and TGN38-IRs were present within the same dendritic shafts (Fig. 2C $C_{1-3}$; CTR433, red; TGN38, green). In confocal longitudinal sections of dendrites double-labeled for TGN38 and synaptophysin (Fig. $2 D_{1,2}$, red and green, respectively) or CTR433 and synapsin (Fig. $2 D_{3,4}$, red and green, respectively), Golgi compartments were mainly localized centrally with respect to the plasma membrane, delineated by green synaptic boutons. At higher magnification (Fig. $2 D_{2}, D_{4}$ ), we observed some punctated elements close to synaptic boutons, beside the central thread of the Golgi apparatus. These little elements were observed with CTR433 as well as with the anti-TGN38 antibody, independently of the presence of the central thread.

\section{Ultrastructural characterization of subsynaptic cisternae}

BiP inside, ribosomal $P$ proteins outside, eIF-2 around

As expected from immunofluorescence experiments, BiP signal strongly labeled the lumenal side of the nuclear envelope (Fig. $3 A_{1}$ ). Cisternae of the smooth endoplasmic reticulum (SER) and RER were strongly labeled (Fig. $3 A_{1}$ ). Bip-IR was also detected in vesicular-shaped elements scattered within the perikaryon. In dendrites, cisternae of different shape and size were observed in the most central part (Fig. $3 A_{2}$ ). In addition, BiP-IR cisternae were often seen in front of presynaptic boutons that could be filled with pleiomorphic (Fig. $3 A_{3,4}$ ) or round vesicles (data not shown). The BiP-positive elements probably corresponded to the fluorescent spots observed throughout the dendritic profiles in confocal sections. Nucleoplasm, Golgi apparatus, mitochondria, and multivesicular bodies in the somatodendritic compartment were unlabeled. Terminal boutons were always devoid of staining.

Ribosomes were detected using the antibody directed against ribosomal $\mathrm{P}$ proteins. In the soma (data not shown) and within dendrites (Fig. $3 B_{1}$ ) the immunogold signal was found in the cytosol, probably associated with free ribosomes, as well as decorating the endoplasmic membranes. More distally, in dendrites, the signal tended to predominate along the plasma membrane. Ribosomal P protein-decorated membranous cisternae were frequently located near synapses and surrounded by clouds of gold particles (Fig. $3 B_{2,3}$ ). In addition, nonmembrane-associated particles were found over weakly electron-dense material, which likely corresponded to free ribosomes. Accretions of ribosomal $\mathrm{P}$ protein-IR were also found at dendritic branching points where clusters of Nissl bodies also accumulate (data not shown). As expected, axoplasm and Golgi complexes were devoid of labeling.

The eIF-2-IR was also present within the somatodendritic compartment as well as near synapses. As for ribosomal $\mathrm{P}$ protein-labeling, somatic staining for eIF-2 was observed associated or not with the RER membranes (data not shown). Beneath postsynaptic differentiations the immunogold particles decorated cisternal- and vesicular-shaped components (Fig. $3 C_{1,2}$ ). In some instances, they could also be detected in a nonmembraneassociated configuration in the vicinity of these cisternae (data not shown).

\section{Golgi markers decorate subsynaptic cisternae}

Because ER markers were present in the vicinity of synapses, we analyzed the distribution of rab1, a marker of early compartments of the secretory pathway, namely the intermediate compartment and the cis-Golgi cisternae (Saraste et al., 1995). In somata, rab1-associated gold particles were found at the cytoplasmic side of the fenestrated cis-Golgi cisternae (Fig. $4 A_{1}$ ). The IR signal was also found associated with more spherical elements scattered in cytosol and likely belonging to the intermediate compartment. Nissl bodies were unlabeled. Under synapses, the signal was mainly associated with cisternous organelles of various sizes and shapes (Fig. $4 A_{2-4}$ ).

CTR433-IR was found within cisternae in the middle of somatic Golgi complexes (data not shown). In the central part of a few dendrites we also observed profiles of Golgi complexes labeled centrally with CTR433-associated gold particles (Fig. 4 $B_{1}$ ). These profiles were infrequent and might correspond to the thread that penetrates a few dendrites seen in the immunofluorescent sections (see above). Regardless of the presence of these Golgi stacks, cisternae positive for CTR433 were observed in the vicinity of postsynaptic differentiations (Fig. $4 B_{2}$ ).

Within perikarya, gold particles associated with anti-TGN38

front of synaptic boutons (arrowheads). Anti-TGN38/anti-synaptophysin and CTR433/anti-synapsin double-labelings are shown in $D_{1}$ and $D_{2}$ and $D_{3}$ and $D_{4}$, respectively. $D_{4}$ is a high magnification of the dendrite in $D_{3} . A-D$ are color-coded pairs of confocal sections. For all antibodies, nuclei were devoid of labeling. $D e$, Dendrites; $n$, nucleus; $s$, soma; $G$, glia. Scale bars, $A_{1-2}: A_{1}, 12 \mu \mathrm{m} ; A_{2}, 5 \mu \mathrm{m} ; B_{1-2}: B_{1}, 14 \mu \mathrm{m} ; B_{2}, 5 \mu \mathrm{m} ; C_{1-3}: C_{1}, 20 \mu \mathrm{m} ; C_{2}, 12 \mu \mathrm{m}$; $C_{3}, 13 \mu \mathrm{m} ; D_{1-4}: D_{1}, 17 \mu \mathrm{m} ; D_{2}, 6 \mu \mathrm{m} ; D_{3}, 21 \mu \mathrm{m} ; D_{4}, 7 \mu \mathrm{m}$. 

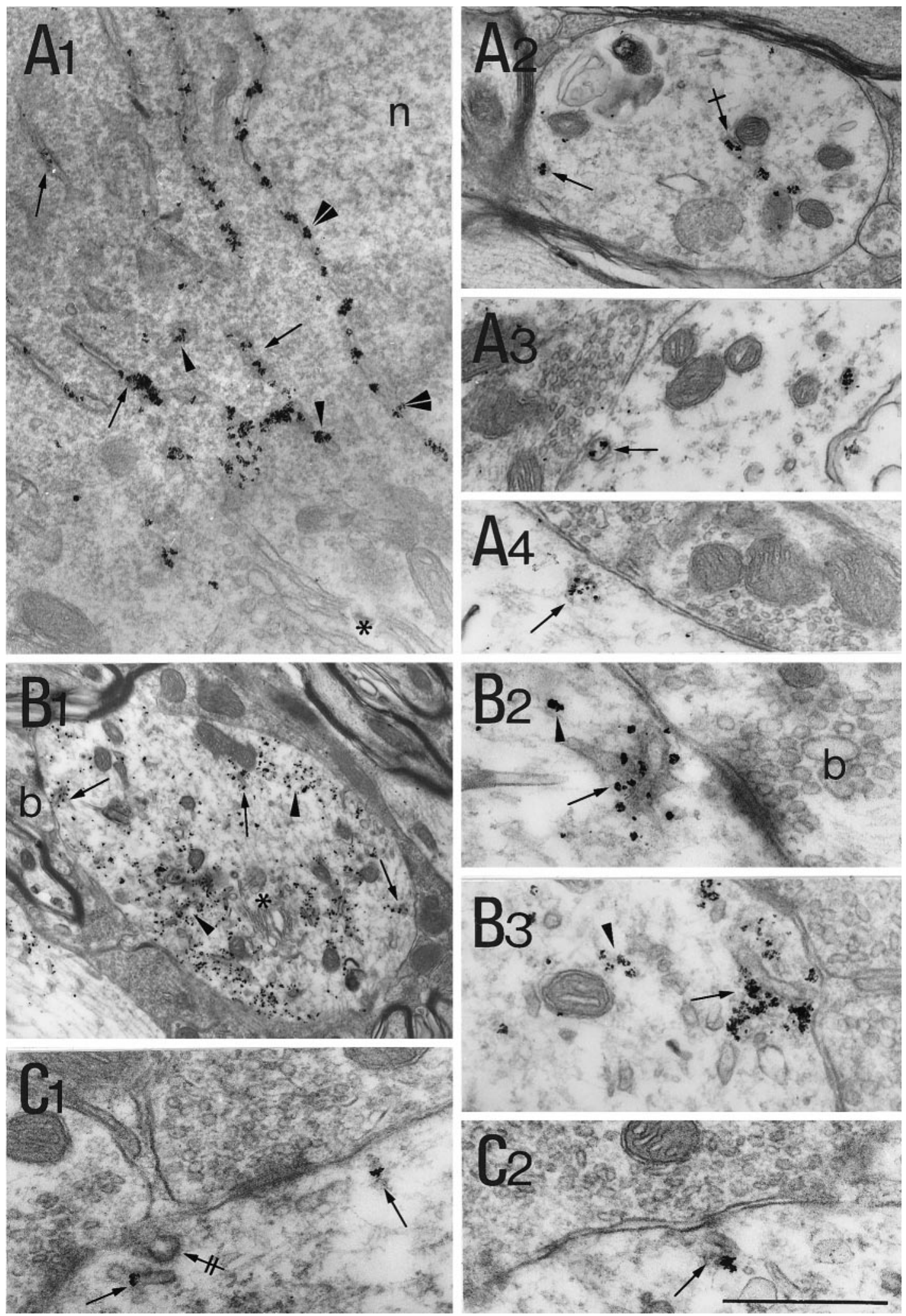

Figure 3. Ultrastructural distribution of elements of the protein synthetic machinery. $A_{1}-A_{4}$, BiP-IR is present in cisternae. $A_{1}$, Presence of IR signal in the nuclear envelope (double arrowheads), in cisternae (arrows), and in vesicular elements (arrowheads). $A_{2}$, Within dendrites gold particles are present within membrane-bounded organelles in the center (crossed arrow) and close to the plasma membrane (arrow). $A_{3}, A_{4}$, BiP-IR within cisternae (arrows) in front of synaptic boutons. $B_{1}-B_{3}$, Ribosomal P protein-IR can be either associated with cisternae (arrows) or free (arrowheads). $B_{2}$ is a higher magnification of $b$ in $B_{1} . B_{3}$, Example from another dendrite. $C_{1}, C_{2}$, Association of eIF-2 $\beta$-IR with postsynaptic cisternae (arrows). Note the presence of coated elements (double-crossed arrow) in the vicinity of labeled cisternae. In all micrographs, Golgi stacks (asterisks), mitochondria, and nucleoplasm ( $n$ ) are devoid of labeling. Scale bar: $A_{1}, A_{2}, 1.5 \mu \mathrm{m} ; A_{3}, A_{4}, 1.1 \mu \mathrm{m} ; B_{1}, 1.9 \mu \mathrm{m} ; B_{2}, B_{3}, C_{1}, C_{2}, 40 \mu \mathrm{m}$. 

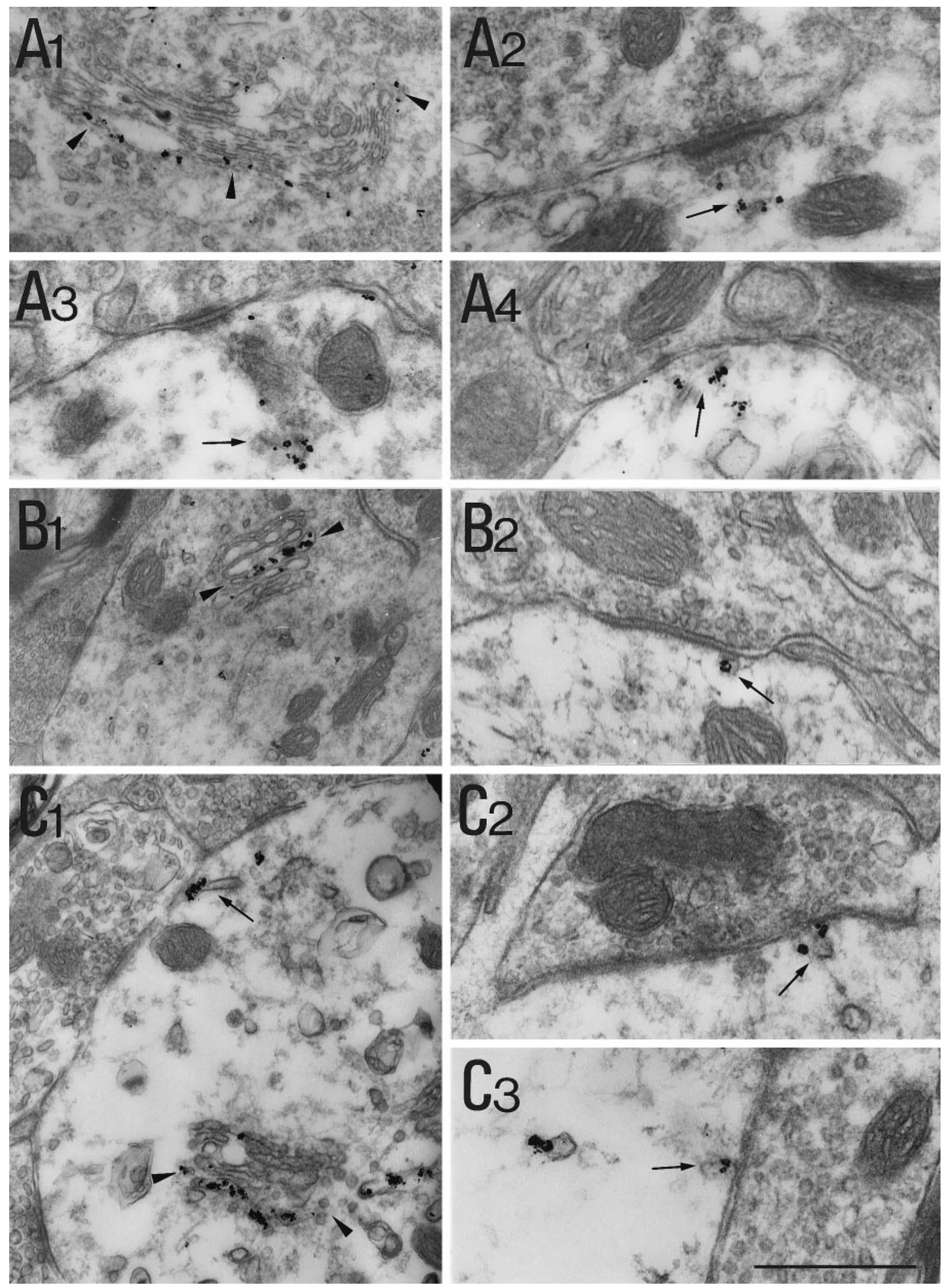

Figure 4. Dendritic and subsynaptic distribution of the postranslational modification machinery. $A_{1}-A_{4}$, rab1-associated gold particles (arrowheads) are found at the cis-side of the Golgi apparatus in the soma $\left(A_{1}\right)$ and associated with cisternae (arrows) in front of synaptic boutons $\left(A_{2}-A_{4}\right)$. $B_{1}, B_{2}$, CTR433-IR labels the lumen of central cisternae (between arrowheads) of a Golgi apparatus within a dendrite. A small vesicular element (arrow) adjacent to a synaptic complex is labeled $\left(B_{2}\right) . C_{1}-C_{3}$, TGN38-IR stains the lumen of external cisternae of the Golgi apparatus (between arrowheads) and cisternae in front of boutons (arrows). Scale bar: $A_{1}, 1 \mu \mathrm{m} ; A_{2}-A_{4}, B_{2}, C_{2}, C_{3}, 0.5 \mu \mathrm{m} ; B_{1}, 1.2 \mu \mathrm{m} ; C_{1}, 0.8 \mu \mathrm{m}$. 


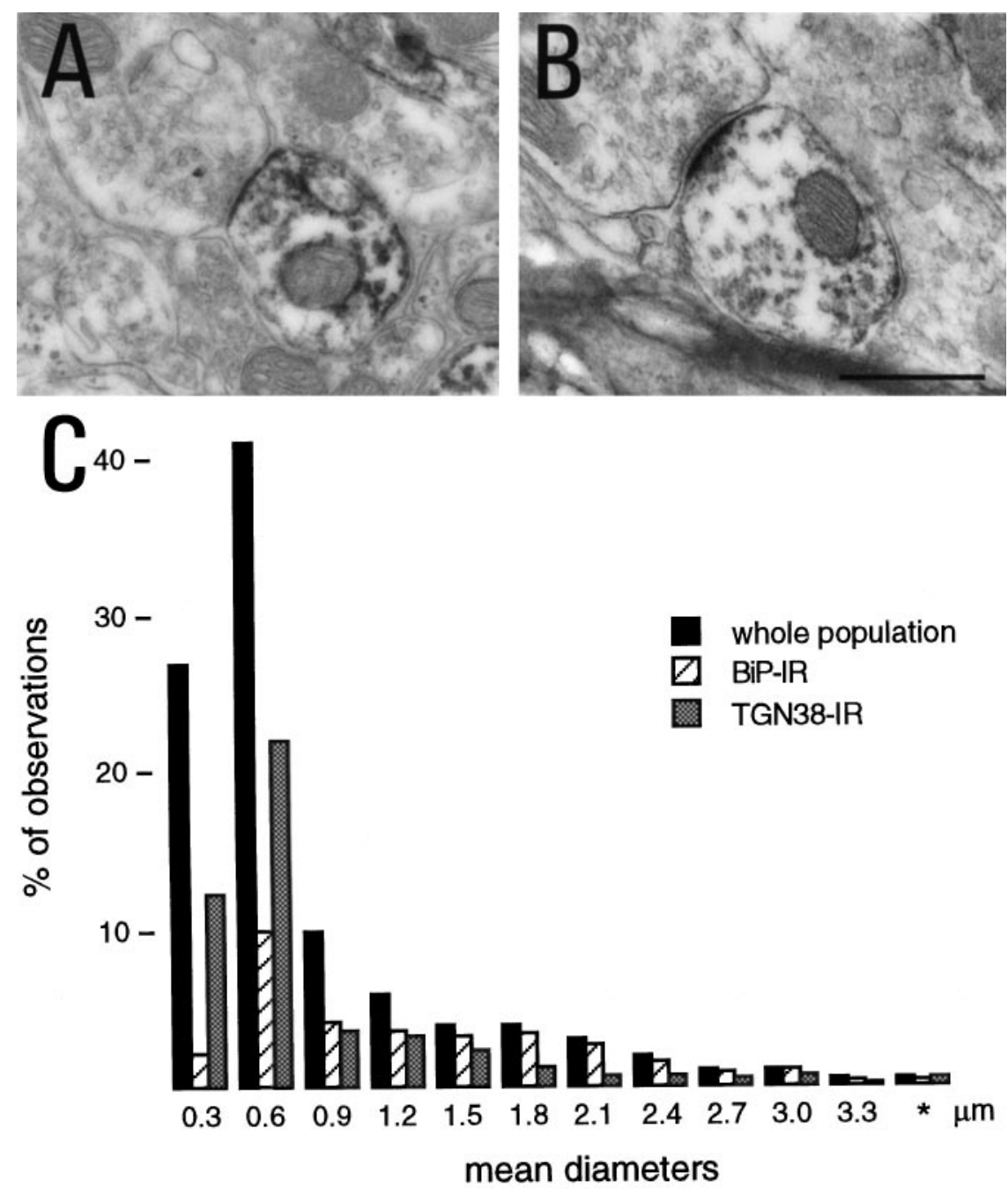

Figure 5. Morphometrical analysis of BiP- and TGN38-IR. $A, B$, BiP- and TGN38-IR profiles connected by synaptic boutons. $C$, Histograms of mean diameters $(\sqrt{ } \mathrm{Ll})$ of dendritic cross sections obtained from two animals and corresponding to the general population $(n=1673)$ and $\operatorname{BiP}-\mathrm{IR}(n=322)$ or TGN38-IR profiles $(n=393)$. Values were grouped in classes of mean diameters with a bin of $0.3 \mu \mathrm{m}$ between 0 and $3.3 \mu \mathrm{m}$, the last class $(*)$ represents diameters $>3.3 \mu \mathrm{m}$. Scale bar: $A, B, 0.5 \mu \mathrm{m}$.

antibodies labeled the lumenal side of cisternae located at the edge of Golgi stacks (data not shown). Thus, we assumed that they correspond to the trans-most side of the Golgi apparatus. In addition, vesicular elements located near these cisternae and scattered throughout the cytoplasm, were immunolabeled. As for the CTR433-IR, TGN38-IR Golgi apparatus were found in few dendrites (exemplified in Fig. $4 C_{1}$ ). In the dendrites as well as in the soma, the trans-cisternae were labeled by TGN38-associated particles. Cisternae labeled with TGN38-IR were observed close to the plasmalemma and quite often underneath synapses (Figs. $\left.4 C_{1-3}\right)$. The gold-toned particles associated with subsynaptic cisternae often overflowed the boundaries of the organelle. This was probably caused by the permeabilization and silverenhancement-gold-toning procedures.

\section{Morphometrical analysis of BiP-IR and TGN38-IR}

The BiP-IR (Fig. 5A) and TGN38-IR (Fig. 5B) were detected even in the smallest dendrites. In some dendrites, the subsynaptic organelles were clearly decorated by the product of the enzymatic reaction, however in most cases, the electron dense reaction product overflowed over the entire dendritic transversal section. This probably resulted from secondary translocation of oxidized DAB (Fig. 5A, $B$ ).

The extension of BiP- and TGN38-IR was indirectly evaluated by comparing the distribution of the diameter of IR profiles to that of the general population of dendrites. This approach assumes that transversal sections of dendrites are of smaller diameter either at distance from the soma or when they are obtained from dendrites of higher order. This notion, which relies on the tapered structure of dendrites, is only statistical (Peters et al., 1991; Chen and Wolpaw, 1994). Measurements of the mean diameter of dendrites seen in cross sections (using the formula $\mathrm{D}=\sqrt{\mathrm{Ll}}$, where $\mathrm{L}$ and 1 are the large and small diameter, respectively) gave $1.23 \mu \mathrm{m} \pm 0.05$ (mean \pm SEM, $n=322$ ), 0.64 $\mu \mathrm{m} \pm 0.028(n=393)$, and $0.55 \mu \mathrm{m} \pm 0.016(n=1673)$ for BiP-IR, TGN38-IR, and the general population of dendrites, respectively. The latter corresponds to all cross sections of dendrites (labeled and unlabeled, $n=871$ for BiP; $n=802$ for TGN38) present in micrographs for immunoenzymatic detection. The general shapes of histograms corresponding to BiP- and TGN38-IRs were comparable to that of the whole population (Fig. 5C). Stained profiles were found in all classes, including those accounting for dendrites of smaller diameter. This suggests that at least in some cases the synthesis apparatus could extend to the dendritic extremities. Interestingly, we found that the frequency of observation of TGN38-IR in small profiles (mean diameter, <0.6) was higher that for the BiP-IR, suggesting that the Golgi apparatus extend further away than the reticulum. 


\section{DISCUSSION}

The requirement of protein synthesis during long-lasting forms of synaptic plasticity has highlighted the functional advantage for a single synapse of accomplishing locally the renewal of its protein set (Kang and Schuman, 1996; Mayford et al., 1996; Martin et al., 1997; Schuman, 1997). Until now, apart from ribosomes, the ultrastructural complement for this mechanism was lacking. The notion of synaptic autonomy (Steward and Levy, 1982; Martin et al., 1997) is supported by our demonstration of the presence of the protein synthetic machinery in the vicinity of the postsynaptic differentiation.

\section{Dendritic localization of the protein synthetic apparatus and the neuronal endomembranous complex}

The subcellular distributions of RER and Golgi apparatus have been described in vivo in many neuronal types and were shown to extend into dendrites (Broadwell and Cataldo 1983; Peters et al., 1991). The distributions of markers of synthetic machinery have been studied by immunocytochemistry in neurons kept in vitro (De Camilli et al., 1986; Lowenstein et al., 1994; Krijnse-Locker et al., 1995; Tiedge and Brosius, 1996). Interestingly, the distribution of the constitutive elements of the machinery seems to depend on cell types and experimental procedures. Our work is the first that combines in vivo confocal and electron microscopic immunocytochemistry to approach the organization of the synthetic apparatus within neurons maintained in their actual network. We have focused our analysis on neurons of the ventromedial laminae of the rat spinal cord, where we previously found a dendritic and postsynaptic localization of GlyR $\alpha$ subunits mRNAs (Racca et al., 1997a, 1998). We found that ribosomes, an initiation factor of protein synthesis (eIF-2), as well as BiP, a chaperone residing in the ER, were somatodendritically distributed. Therefore, in spinal cord neurons, the distribution of ribosomal $\mathrm{P}$ proteins and eIF-2 IRs was comparable to that found in cultured hippocampal neurons (Tiedge and Brosius, 1996). Ribophorin (Torre and Steward, 1996) was also detected in proximal to mid dendrites, whereas another ER marker (TRAP/SSR) was found in somata and proximal dendrites (Krijnse-Locker et al., 1995) and occasionally more distally (Tiedge and Brosius, 1996). Our EM morphometrical analysis suggests that ER extend over the whole length of some dendrites. The Golgi apparatus identified with antibodies against TGN38 (trans-most cisternae and trans-Golgi network) and CTR433 (medial cisternae) shows the same somatodendritic pattern. Others found that TGN38-IR Golgi tubules are confined to the cell bodies (Krijnse-Locker et al., 1995) or detected in proximal and, infrequently, in distal dendrites (Torre and Steward, 1996). Our EM measurements indicate that TGN38 labeling could extend into distal dendrites.

Like other authors (Dotti and Simons 1990; Lowenstein et al., 1994; Torre and Steward, 1996), we found that the Golgi elements connected with the somatic ones penetrated only few dendrites (two or three in $96 \%$ of the neurons). The strongest dendritic ER and mRNA signals were present within the principal dendrites where the Golgi apparatus had the classical thread-like structure. This association suggests that this distribution may have a physiological meaning. In addition to this dendritic central threadshaped Golgi connected with its somatic counterpart, discontinuous punctate TGN38- and CTR433-IR elements were observed not only in the principal dendrite(s) but also in others. In doublelabeling experiments (anti-TGN-38 and anti-synaptophysin; CTR433 and anti-synapsyn), these Golgi elements, defined by their immunoreactivities, were present under synapses. Therefore, the Golgi apparatus could display a thread-like structure connected with the somatic network and present in few dendrites, or a vesicular structure present in many more dendrites often in front of synaptic contacts. Yet the Golgi apparatus is a highly dynamic structure (Sciaky et al., 1997). In muscular cells, dramatic changes in Golgi distributions are observed during synaptogenesis and denervation (Jasmin et al., 1989, 1995). We, therefore, suggest that the tubular-shaped Golgi apparatus could move into some dendrites in which high levels of synthesis are required. The vesicular-shaped CTR433 and TGN38-IR structures could then correspond to elements of the Golgi complex that would have remained at specific sites after the withdrawal of the main thread-shaped Golgi apparatus.

\section{Subsynaptic cisternae and receptor synthesis}

Subsurface and hypolemmal cisternae have been described in several types of central neurons, including spinal neurons (Rosenbluth, 1962; Bodian, 1965; Kaiserman-Abramof and Palay, 1969; Peters et al., 1991). The morphology and localization of these elements varies within and from one neuronal type to another. These morphological differences could be associated with different functions. Bodian (1965) was the first to postulate a "trophic" (protein synthesis) function for them. In the spinal cord, most of the postsynaptic sites display a complex array of cisternae. We found in spinal cord neurons that some subsynaptic cisternae are BiP-positive. The presence of BiP indicates that these cisternae are compartments where neosynthesized proteins can be properly translocated and folded (Haas and Wabl, 1983; Bole et al., 1986; Gething and Sambrook, 1992). We have also detected ribosomal $\mathrm{P}$ protein-IR around these cisternae. The presence of pericisternal ribosomes and initiation factors (both detected by immunocytochemistry) support the notion that some of these cisternae correspond to RER and could achieve the synthesis of transmembrane proteins. Ribosomes and initiation factors not associated with cisternae could participate in the synthesis of cytosolic and perisynaptic proteins involved in other synaptic functions for which the presence of the corresponding mRNAs was reported in dendrites (e.g., MAP2, Davis et al., 1987; Garner et al., 1988; the $\alpha$ subunit of the calcium/calmodulin-dependent kinase, Burgin et al., 1990; Arc, Link et al., 1995, Lyford et al., 1995; for review, see Steward et al., 1996). Cisternae were also labeled by markers of the medial-Golgi (CTR433) and the trans-Golgi network and cisternae (anti-TGN38). Rab1, a member of the rab family involved in the routing between cisternae that synthesize proteins and cis-Golgi, was also found near synapses. The question remained whether or not the postsynaptic cisternae stained for the various antibodies were distinct elements. It is generally accepted that the synthetic transport pathway for membrane proteins is the same in all eukaryotes. It is composed of distinct compartments, and the vectorized routing passes sequentially from RER to Golgi and then to plasma membrane (Pelham and Munro, 1993). This general scheme of organization probably also holds for the postsynaptic synthetic machinery. None of the antibodies labeled all of the postsynaptic membrane-limited structures. Moreover, as seen with double immunofluorescence experiments, TGN38- and BiP-IRs were not colocalized but rather juxtalocalized. This indicates that subsynaptic cisternae stained by each antibody were different entities. Therefore, we postulate that the collection of postsynaptic cisternal elements form a local synthetic/secretion machinery constituted by adjacent compartments with defined functions located near synapses. 


\section{Glycosylation in dendrites}

The presence of mRNAs encoding receptors in dendrites (Furuichi et al., 1993; Miyashiro et al., 1994; Racca et al., 1997a), has pointed to the requirement for machinery allowing translocation and glycosylation of the corresponding proteins. Autoradiographic analysis of synaptosomes (Rao and Steward, 1991) and isolated dendrites (Torre and Steward, 1992) has shown an incorporation of radiolabeled amino acids, thus indicating translational activity performed by nonsomatic compartments. Using the same system (i.e., dendrites isolated from neuronal cultures), Torre and Steward (1996) have shown that dendrites may also undergo glycosylation. Indeed, they found that the percentage of dendrites incorporating radiolabeled glycosylation precursors was greater than the percentage of dendrites immunopositive for Golgi markers. They conclude that this underestimation could be caused by either culture differences or the existence of a population of dendrites exhibiting glycosylation activity without detectable Golgi apparatus immunoreactivity. Our results support the latter hypothesis. The Golgi-like cisternae that we found with a punctate fluorescent staining under synapses were present in many dendrites where the thread-like Golgi apparatus could not be detected. At the EM level, some of these elements correspond to cisternae that do not display the classical conformation of Golgi stacks. We hypothesize that the cisternae immunopositive for these Golgi markers could be responsible for dendritic and subsynaptic glycosylation.

\section{Conclusions}

Long-term potentiation at single synapses in hippocampal slices has been shown to be dependent on exocytosis in the postsynaptic cell (Lledo et al., 1998). This secretion-dependent plasticity could result from (1) exocytosis of retrograde messengers or (2) delivery of receptor that could be stored and/or synthesized under the synapse. The nature of the signal that could trigger these local modifications is unknown. Within dendrites some cisternae are involved in the sequestration (Villa et al., 1991; Takei et al., 1992) and regulation of the cytosolic concentration (Llano et al., 1994) of calcium. Local modifications of the concentration of calcium, before or during its storage in subsynaptic cisternae (PozzoMiller et al., 1997), may be the first step in a signaling cascade leading to the insertion of newly synthesized molecules. After "activation" of synaptically localized silent mRNAs, the protein synthesis of specific proteins may be restricted to the single previous-activated synapse. The cisternae that we have characterized and which are likely to be involved in local protein synthesis and insertion may be different from those involved in calcium storage (Pozzo-Miller et al., 1997). Therefore, the subpostsynaptic region may include a complex array of organelles ensuring the functional autonomy of the synapse.

\section{REFERENCES}

Bloom FE, Ueda T, Battenberg E, Greengard P (1979) Immunocytochemical localization, in synapses, of protein I, an endogenous substrate for protein kinases in mammalian brain. Proc Natl Acad Sci USA 76:5982-5986.

Bodian D (1965) A suggestive relationship of nerve cell RNA with specific synaptic sites. Proc Natl Acad Sci USA 53:418-425.

Bole DG, Hendershot LM, Kearney JF (1986) Posttranslational association of immunoglobulin heavy chain binding protein with nascent heavy chains in nonsecreting and secreting hybridomas. J Cell Biol 102:1558-1566.

Bommer UA, Lutsch G, Behlke J, Stahl J, Nesytova N, Henske A, Bielka $\mathrm{H}$ (1988) Shape and location of eukaryotic initiation factor eIF-2 on the $40 \mathrm{~S}$ ribosomal subunit of rat liver, immunoelectron-microscopic and hydrodynamic investigations. Eur J Biochem 172:653-662.
Broadwell RD, Cataldo AM (1983) The neuronal endoplasmic reticulum: its cytochemistry and contribution to the endomembrane system. I. Cell bodies and dendrites. J Histochem Cytochem 31:1077-1088.

Burgin KE, Waxham MN, Rickling S, Westgate SA, Mobley WC, Kelly PT (1990) In situ hybridization histochemistry of Ca2+/calmodulindependent protein kinase in developing rat brain. $\mathrm{J}$ Neurosci 10:1788-1798.

Chen XY, Wolpaw JR (1994) Triceps surae motoneuron morphology in the rat: a quantitative light microscopic study. J Comp Neurol 343:143-157.

Davis L, Banker GA, Steward O (1987) Selective dendritic transport of RNA in hippocampal neurons in culture. Nature 330:477-479.

De Camilli P, Cameron R, Greengard P (1983) Synapsin I (protein I), a nerve terminal-specific phosphoprotein. I. Its general distribution in synapses of the central and peripheral nervous system demonstrated by immunofluorescence in frozen and plastic sections. J Cell Biol 96:1337-1354.

De Camilli P, Moretti M, Donini DS, Walter U, Lohmann SM (1986) Heterogeneous distribution of the cAMP receptor protein RII in the nervous system: evidence for its intracellular accumulation on microtubules, microtubule-organizing centers, and in the area of the Golgi complex. J Cell Biol 103:189-203.

Dotti CG, Simons K (1990) Polarized sorting of viral glycoproteins to the axon and dendrites of hippocampal neurons in culture. Cell 62:63-72.

Elkon KB, Parnassa AP, Foster CL (1985) Lupus autoantibodies target ribosomal P proteins. J Exp Med 162:459-471.

Elkon K, Skelly S, Parnassa A, Moller W, Danho W, Weissbach H, Brot N (1986) Identification and chemical synthesis of a ribosomal protein antigenic determinant in systemic lupus erythematosus. Proc Natl Acad Sci USA 83:7419-7423.

Furuichi T, Simon-Chazottes D, Fujino I, Yamada N, Hasegawa M, Miyawaki A, Yoshikawa S, Guenet JL, Mikoshiba K (1993) Widespread expression of inositol 1,4,5-triphosphate receptor type I gene (InsP3R1) in the mouse central nervous system. Receptors Channels $1: 11-24$.

Gardiol A, Racca C, Rios RM, Bornens M, Triller A (1997) Dendritic and subsynaptic organelles involved in synthesis of transmembrane proteins. Soc Neurosci Abstr 23:260.4.

Garner CC, Tucker RP, Matus A (1988) Selective localization of messenger RNA for cytoskeletal protein MAP2 in dendrites. Nature 336:674-677.

Gething MJ, Sambrook J (1992) Protein folding in the cell. Nature 355:33-45.

Haas IG, Wabl M (1983) Immunoglobulin heavy chain binding protein. Nature 306:387-389.

Jasmin BJ, Cartaud J, Bornens M, Changeux JP (1989) Golgi apparatus in chick skeletal muscle: changes in its distribution during end plate development and after denervation. Proc Natl Acad Sci USA 86:7218-7222.

Jasmin BJ, Antony C, Changeux JP, Cartaud J (1995) Nerve-dependent plasticity of the Golgi complex in skeletal muscle fibres: compartmentalization within the subneural sarcoplasm. Eur J Neurosci 7:470-479.

Kaiserman-Abramof IR, Palay SL (1969) Fine structural studies of the cerebellar cortex in a mormyrid fish. Neurobiology of cerebellar evolution and development. (Llinàs R, ed), pp 171-205. Chicago: American Medical Association.

Kang H, Schuman EM (1996) A requirement for local protein synthesis in neurotrophin-induced hippocampal synaptic plasticity. Science 273:1402-1406.

Krijnse-Locker J, Parton RG, Fuller SD, Griffiths G, Dotti CG (1995) The organization of the endoplasmic reticulum and the intermediate compartment in cultured rat hippocampal neurons. Mol Biol Cell 6:1315-1332.

Kuhse J, Schmieden V, Betz H (1990) A single amino acid exchange alters the pharmacology of neonatal rat glycine receptor subunit. Neuron 5:867-873.

Link W, Konietzko U, Kauselmann G, Krug M, Schwanke B, Frey U, Kuhl D (1995) Somatodendritic expression of an immediate early gene is regulated by synaptic activity. Proc Natl Acad Sci USA 92:5734-5738.

Llano I, DiPolo R, Marty A (1994) Calcium-induced calcium release in cerebellar Purkinje cells. Neuron 12:663-673.

Lledo PM, Zhang X, Südhof TC, Malenka RC, Nicoll RA (1998) 
Postsynaptic membrane fusion and long-term potentiation. Science 279:399-403.

Lowenstein PR, Morrison EE, Bain D, Shering AF, Banting G, Douglas P, Castro MG (1994) Polarized distribution of the trans-Golgi network marker TGN38 during the in vitro development of neocortical neurons: effects of nocodazole and brefeldin A. Eur J Neurosci 6:1453-1465.

Lyford GL, Yamagata K, Kaufmann WE, Barnes CA, Sanders LK, Copeland NG, Gilbert DJ, Jenkins NA, Lanahan AA, Worley PF (1995) Arc, a growth factor and activity-regulated gene, encodes a novel cytoskeleton-associated protein that is enriched in neuronal dendrites. Neuron 14:433-445.

Malosio ML, Marquèze-Pouey B, Kuhse J, Betz H (1991) Widespread expression of glycine receptor subunit mRNAs in the adult and developing rat brain. EMBO J 9:2401-2409.

Martin KC, Casadio A, Zhu H, E Y, Rose JC, Chen M, Bailey CH, Kandel ER (1997) Synapse-specific, long-term facilitation of aplysia sensory to motor synapses: a function to local protein synthesis in memory storage. Cell 91:927-938.

Mayford M, Baranes D, Podsypanina K, Kandel ER (1996) The 3'untranslated region of $\mathrm{CaMKII} \alpha$ is a cis-acting signal for the localization and translation of mRNA in dendrites. Proc Natl Acad Sci USA 93:13250-13255.

Miyashiro K, Dichter M, Eberwine J (1994) On the nature and differential distribution of mRNAs in hippocampal neurites: implications for neuronal functioning. Proc Natl Acad Sci USA 91:10800-10804.

Pelham HRB, Munro S (1993) Sorting of membrane proteins in the secretory pathway. Cell 75:603-605.

Peters A, Palay SL, Webster H de F (1991) The fine structure of the nervous system. Neurons and their supporting cells. Oxford: Oxford UP.

Pozzo-Miller LD, Pivovarova NB, Leapman RD, Buchanan RA, Reese TS, Andrews BS (1997) Activity-dependent calcium sequestration in dendrites of hippocampal neurons in brain slices. J Neurosci 17:8729-8738.

Racca C, Gardiol A, Triller A (1997a) Dendritic and postsynaptic localizations of glycine receptor $\alpha$ subunit mRNAs. J Neurosci 17:1691-1700.

Racca C, Gardiol A, Triller A (1997b) Nova-1: an RNA-binding protein associated with GlyR $\alpha 2$ subunit mRNAs in rat spinal cord. Soc Neurosci Abstr 23:486.4.

Racca C, Gardiol A, Triller A (1998) Cell-specific dendritic localization of glycine receptor $\alpha$ subunit messenger RNAs. Neuroscience 84:997-1012.

Rao A, Steward O (1991) Evidence that protein constituents of the postsynaptic membrane specializations are locally synthesized: analysis of proteins synthesized within synaptosomes. J Neurosci 11:2881-2895.

Rhoads RE (1993) Regulation of eukaryotic protein synthesis by initiation factors. J Biol Chem 268:3017-3020.

Rosenbluth J (1962) Subsurface cisterns and their relationship to the neuronal plasma membrane. J Cell Biol 13:405-421.

Saraste J, Lahtinen U, Goud B (1995) Localization of the small GTP- binding protein rab1p to early compartments of the secretory pathway. J Cell Sci 108:1541-1552.

Schuman EM (1997) Synapse specificity and long-term information storage. Neuron 18:339-342.

Sciaky N, Presley J, Smith C, Zaal KJ, Cole N, Moreira JE, Terazaqui M, Siggia E, Lippincott-Schwartz J (1997) Golgi tubule traffic and the effects of brefeldin A visualized in living cells. J Cell Biol 139:1137-1155.

Stanley KK, Howell KE (1993) TGN38/41: a molecule on the move. Trends Cell Biol 3:252-255.

Steward O (1997) mRNA localization in neurons: a multipurpose mechanism? Neuron 18: 9-12.

Steward O, Banker GA (1992) Getting the message from the gene to the synapse: sorting and intracellular transport of RNA in neurons. Trends Neurosci 15:180-186.

Steward O, Levy WB (1982) Preferential localization of polyribosomes under the base of dendritic spines in granule cells of the dentate gyrus. J Neurosci 2:284-291.

Steward O, Reeves TM (1988) Protein-synthetic machinery beneath postsynaptic sites on CNS neurons: association between polyribosomes and other organelles at the synaptic site. J Neurosci 8:176-184.

Steward 0, Kleinman R, Banker G (1996) Subcellular localization of mRNA in neurons. Localized mRNAs molecular biology intelligence unit series (Lipshitz HD, ed), pp 235-255. Boca Raton, FL: CRC.

Takei K, Stukenbrok H, Metcalf A, Mignery GA, Südhof TC, Volpe P, De Camilli P (1992) $\mathrm{Ca}^{2+}$ stores in Purkinje neurons: endoplasmic reticulum subcompartments demonstrated by the heterogeneous distribution of the $\mathrm{InsP}_{3}$ receptor, $\mathrm{Ca}^{2+}$-ATPase, and calsequestrin. J Neurosci 12:489-505.

Tiedge H, Brosius J (1996) Translational machinery in dendrites of hippocampal neurons in culture. J Neurosci 16:7171-7181.

Torre E, Steward O (1992) Demonstration of local protein synthesis within dendrites using a new cell culture system that permits the isolation of living axons and dendrites from their cell bodies. J Neurosci 12:762-772.

Torre E, Steward O (1996) Protein synthesis within dendrites: glycosylation of newly synthesized proteins in dendrites of hippocampal neurons in culture. J Neurosci 16:5967-5978.

Trembleau A, Morales M, Bloom FE (1994) Aggregation of vasopressin mRNA in a subset of axonal swellings of the median eminence and posterior pituitary: light and electron microscopic evidence. J Neurosci 14:39-53.

Villa A, Podini P, Clegg DO, Pozzan T, Meldolesi J (1991) Intracellular $\mathrm{Ca}^{2+}$ stores in chicken Purkinje neurons: differential distribution of the low affinity-high capacity $\mathrm{Ca}^{2+}$ binding protein, calsequestrin, of $\mathrm{Ca}^{2+}$ ATPase and of the ER lumenal protein, BiP. J Cell Biol 113:779-791.

Wiedenmann B, Franke WW (1985) Identification and localization of synaptophysin, an integral membrane glycoprotein of $\mathrm{Mr} 38,000$ characteristic of presynaptic vesicles. Cell 41:1017-1028.

Wilde A, Reaves B, Banting G (1992) Epitope mapping of two isoforms of a trans-Golgi network specific integral membrane protein TGN38/41. FEBS Lett 313:235-238. 